\title{
Michał Herer
}

\section{Od ontologii \\ do etyki wydarzenia}

Tekst stanowi próbę podwójnej lektury Deleuzjańskiej Logiki sensu jako, z jednej strony, ontologii niecielesnych wydarzeń, z drugiej zaś - etyki wzywającej do „bycia godnym tego, co nam się przydarza”. Ten pierwszy aspekt wiąże się z koniecznością przezwyciężenia fenomenologii i zrewidowania założeń filozofii transcendentalnej. Z kolei swoją etykę wydarzenia Deleuze rozwija, nawiązując do stoików i Nietzschego, a także pisarzy takich jak Bousquet, Lowry czy Fitzgerald. Opiera się ona na imperatywie afirmacji świata jako stawania się - afirmacji zarówno na płaszczyźnie albo powierzchni czystej myśli, jak i we własnym ciele, dla którego jednak oznacza to zawsze ranę, zagrożenie rozpadem.

Słowa kluczowe: to, co niecielesne, wydarzenie, sens, paradoks, etyka, wieczny powrót, stoicy, afirmacja, atletyzm 
Dyskusję o Logice sensu należałoby może zacząć od - banalnej na pozór - uwagi, że mamy tu do czynienia z książka, Deleuze zaś był filozofem piszącym książki. Co właściwie czyni książkę książką? A w szczególności - książką filozoficzną? Co czyni nią Logikę sensu?

Po pierwsze, względna autonomia myśliciela w stosunku do warunków zewnętrznych. Książka powstaje dlatego, że musi powstać, jest to jednak konieczność innego rodzaju niż ta wynikająca z akademickiego kalendarza. Deleuze, mimo że sam był wykładowcą - Różnicę i powtórzenie $^{1}$ (wraz z równie obszernym traktatem o Spinozie ${ }^{2}$ ) przedstawił na Sorbonie jako rozprawę doktorską - mógł sobie pozwolić na pewną swobodę wobec wymogów życia uniwersyteckiego. Być może jest to kwestia zmieniających się czasów, mniejszej presji instytucjonalnej (dotyczącej publikacji, udziału w konferencjach, sesjach naukowych itd.), jakiej podlegali akademicy pół wieku temu - tak czy inaczej, autor wydanej w 1953 roku monografii poświęconej Hume'owi ${ }^{3}$ nie opublikował żadnego większego dzieła aż do pracy na temat filozofii Nietzschego w roku $1962^{4}$. Rzecz trudna do wyobrażenia w dzisiejszych warunkach produkcji wiedzy... Oto jak wspominał ów okres w jednym z wywiadów: „To prawdziwa dziura w moim życiu, dziura rozciągająca się na osiem lat. Właśnie takie dziury wydają mi się interesujące w życiu ludzi”s. Wiele mówi się dzisiaj na temat ekspansji mediów elektronicznych i rychłego „końca książki”, jeśli jednak koniec ów rzeczywiście nastąpi, to nie ze względu na zmianę medium, lecz na skutek likwidacji warunków, dzięki którym prawdziwe książki (niebędące zbiorami artykułów ani tomami pokonferencyjnymi) mogą dojrzewać właśnie w takich interesujących dziurach. To w nich, jak wyjaśnia Deleuze, „dokonuje się ruch”6.

Po drugie, autonomia w planie ściśle teoretycznym - każda książka zarysowuje odrębną problematykę, wymagającą do swojej eksplikacji odrębnego zestawu pojęć. Nie wyklucza to oczywiście ciągłości myśli,

1 G. Deleuze, Różnica i powtórzenie, tłum. B. Banasiak, K. Matuszewski, Warszawa 1997.

2 tegoż, Spinoza et le problème de l'expression, Paris 1968.

3 Tegoż, Empiryzm i subiektywność: esej o naturze ludzkiej wedtug Huméa, tłum. K. Jarosz, Warszawa 2000.

4 Tegoż, Nietzsche i filozofia, tłum. B. Banasiak, Warszawa 1993.

5 Tegoż, Negocjacje 1972-1990, tłum. M. Herer, Wrocław 2007, s. 147-148.

6 Tamże. W jego wypadku ruch ten doprowadził właśnie do przełomowej interpretacji myśli Nietzschego, a następnie, w ciągu kilku ostatnich lat dekady, do prawdziwej pisarskiej erupcji, której efektem będzie nie tylko Logika sensu oraz Różnica i powtórzenie, ale też prace o Kancie, Bergsonie, Prouście, Spinozie i Sacher-Masochu... 
meandrycznej linii łączącej dzieła napisane przez jednego filozofa. Myśl ta rozwija się jednak właśnie „z książki na książkę”. Jaki nowy problem podejmuje Deleuze w Logice sensu? Odpowiedzi dostarcza poniekąd sam tytuł; mówiąc jednak bardziej ogólnie, chodzi o zagadnienie tego, co niecielesne. W jaki sposób dzisiaj, czyli przede wszystkim: po Nietzschem, filozofia ma mówić o niecielesnym? Temu właśnie służy Deleuzjańskie pojęcie wydarzenia.

Po trzecie, autonomia formy. Deleuze przeczuwał, że „nadchodzi czas, kiedy napisanie książki filozoficznej w taki sposób, w jaki czyniono to od dawna, nie będzie już możliwe"7. I nawet jeśli większość jego kolegów po fachu wciąż pisze jak „od dawna”, to dla niego samego $\mathrm{w}$ pewnym momencie nadszedł czas na zerwanie nie tylko z formą historyczno-filozoficznej monografii, lecz także z klasyczną formą rozprawy, w której mieści się jeszcze Różnica i powtórzenie. Forma książki filozoficznej musi być wynaleziona na nowo; co więcej - musi być wynajdowana za każdym razem, towarzysząc kreacji ściśle pojęciowej i ją uzupełniając. Często przywołuje się słowa Deleuze’a o tym, że każdy wielki filozof był zarazem wielkim stylistą, trzeba jednak pamiętać o tym, czym był dla niego styl. Otóż od stylu - a nawet, szerzej: od twórczości jako takiej - nie da się oddzielić pewnej zasadniczej niemożności. Nie można już pisać tak, jak się pisało, i właśnie z tej niemocy czerpie swą siłę eksperyment dotyczący formy. Niektóre książki Deleuze’a, zwłaszcza napisane w tandemie z Guattarim Mille Plateaux, do dziś wywołują konfuzję. Z czym mamy tu właściwie do czynienia? Z traktatem ontologicznym? Zbiorem wariacji na kilka luźno powiązanych tematów? Czym są owe plateaux i jak wyglądałaby książka składająca się z tysiąca takich ,jednostek"? W Logice sensu eksperyment nie idzie jeszcze tak daleko, choć już tu pojawia się nowa forma, a mianowicie forma serialna. Na ile koresponduje ona z filozoficzną treścią tej książki, tak jak forma plateaux korespondować będzie z ontologią kłącza ${ }^{8}$ ?

I wreszcie, Logika sensu, jak większość prawdziwych książek filozoficznych, poddaje się swoistej podwójnej lekturze. Można do niej odnieść stwierdzenie samego Deleuze'a na temat Spinozjańskiej Etyki. Tak, jak ciąg przedstawianych przez Spinozę more geometrico twierdzeń i dowodów jest stale podwajany przez „kręty łańcuch wulkaniczny” przypisków, tworzących „coś w rodzaju drugiej Etyki, która współistnieje z pierwszą,

7 G. Deleuze, Różnica i powtórzenie, s. 24.

8 Zob. G. Deleuze, F. Guattari, Ktacze, tłum. B. Banasiak, „Colloquia Communia" 1988, nr 1-3, s. 221-237. 
mając jednak zupełnie inny rytm, inny ton"9 ${ }^{\text {, }}$ podobnie Deleuzjańską teorię sensu zdaje się podwajać jakiś inny, podziemny tekst. Owa druga Logika jest przy tym właśnie swoistą etyką, neostoicką etyką bezcielesnego wydarzenia, „dublującą ruch pojęcia całą mocą afektu” ${ }^{10}$. Przyjrzyjmy się bliżej tym dwóm rejestrom.

\section{I}

Pierwszy z nich - na którym koncentruje się większość komentatorów i któremu poświęcimy tu mniej miejsca - obejmuje ontologię sensu, będącą jednocześnie jego logiką i fizyką. Jeśli idzie o pierwszy z tych członów, już na samym początku daje o sobie znać osobliwa strategia związana z zastosowaniem paradoksu. Logika sensu, powiada Deleuze, musi być logiką paradoksalną, opartą na paradoksie: „Nie powiemy [...], że paradoksy oferują zniekształcony obraz myślenia - nieprawdopodobny i niepotrzebnie skomplikowany. Trzeba chyba samemu być zbyt "prostym«, by uznać myślenie za nieskomplikowaną czynność, przejrzystą dla siebie samej, która nie uruchamia wszelkich mocy nieświadomości, wraz z wtopionym w nią nonsensem" ${ }^{11}$. Deleuzjański obraz myśli nigdy nie był prosty i właśnie dlatego paradoks odgrywa tu szczególną rolę. Nie jest ani przeszkodą w formułowaniu jasnych twierdzeń, czymś, co myśl powinna przezwyciężyć, by wkroczyć do królestwa prawdy, źródłem niebezpiecznego zamętu, ani przedmiotem inteligentnej rozrywki dla myśli zmęczonej rozwiązywaniem poważnych problemów. Pozwala jej raczej dopiero dotrzeć do tego, co problematyczne. Jest to bowiem możliwe tylko pod warunkiem przekroczenia dwóch krępujących ruchy myślenia form - zdrowego rozsądku i zmysłu wspólnego. Zdrowy rozsądek zawsze wyznacza jeden właściwy, dobry kierunek [bon sens]. „Paradoks jako pasja myślenia odkrywa wszakże, iż oba kierunki są nierozłączne, a ustalenie jednego kierunku nie jest możliwe, nie ma jednego kierunku dla poważnej myśli czy pracy i odwrotnego kierunku dla rozrywki czy marginalnych zabaw” ${ }^{2}$. „Z kolei w przypadku zmysłu wspólnego chodzi nie tyle o kierunek, ile o pewien organ. I jeśli nazywa się go wspólnym, to dlatego, że jest organem, funkcją, zdolnością iden-

9 G. Deleuze, Negocjacje, s. 171.

10 Tamże.

11 G. Deleuze, Logika sensu, tłum. G. Wilczyński, Warszawa 2011, s. 111.

12 Tamże, s. 114. 
tyfikacji sprowadzającą dowolną różnorodność do postaci Tego Samego"13. Paradoks usuwa ten organ, w wyniku czego żadne oczywiste rozpoznanie nie jest już możliwe, a różnorodność jawi się w całej swej pozytywnej złożoności.

Dopiero tak „zdezorientowana” i „zdezorganizowana” myśl może zmierzyć się z pytaniem o to, co niecielesne. W dwudziestym wieku owo pytanie przybiera jednak przede wszystkim postać pytania o sens. Dlatego nowa logika bezcielesnego musi być właśnie logiką sensu, a zarazem wyzwaniem rzuconym wszystkim tym, którym ten ostatni jawi się jako coś prostego, nierozkładalnego, źródłowego. Musi być wyzwaniem rzuconym fenomenologii, a nawet - szerzej - całej tradycji filozofii transcendentalnej. Podstawowa teza tej logiki brzmi, że sens jest zawsze efektem, wytworem, produktem czegoś innego niż on sam, że sens nie rodzi się z sensu, że jest hetero-geniczny (nie tylko zróżnicowany, ale pochodzący od tego, co od niego różne, od rozmaitych postaci non-sensu, i naznaczony piętnem tego pochodzenia, ową głębszą albo bardziej radykalną postacią różnicy). Zdrowy rozsądek dopuszcza możliwość osuwania się sensu w bezsens $\mathrm{i}$ już to próbuje powstrzymać ten proces $\mathrm{z}$ iście policyjną gorliwością i z zastosowaniem rozmaitych technik prewencyjnych, już to akceptuje go na zasadach niezobowiązującej, dowcipnej gry. Tym, co absolutnie niedopuszczalne, jest dla niego natomiast jednoczesność dwóch kierunków, obecność bezsensu w sensie i wyłanianie się drugiego z pierwszego. Czy jednak już Husserl nie wykracza poza ten horyzont, mówiąc o konstytucji sensu? Sprawa jest niezwykle złożona, o czym wiedzą zwłaszcza czytelnicy jego ineditów, przechowywanych $\mathrm{w}$ archiwum w Louvain. Zagadnienie „pasywnych syntez” i swoista transcendentalna proto-logika, nad którą autor Idei pracował w latach dwudziestych ubiegłego wieku ${ }^{14}$, dają się interpretować zarówno w duchu fenomenologicznej ortodoksji, jak i w duchu bardziej heretyckim, który otwiera przed filozofią transcendentalną nowe horyzonty. Deleuze widzi obie te możliwości, ostatecznie jednak dystansuje się od myśli Husserla jako wyrazu doksy, jeśli nie spod znaku zdrowego rozsądku, to przynajmniej spod znaku zmysłu wspólnego, który „przyjmuje z dobrodziejstwem inwentarza [...], to, co transcendentalne, przedstawiając w postaci Osoby lub Ego"15.

13 Tamże.

14 Zob. E. Husserl, Analysen zur passiven Synthesis: aus Vorlesungs- und Forschungsmanuskripten (1918-1926), [w:] Husserliana: Edmund Husserl Gesammelte Werke, t. 11, Haag 1996 (tłum. fr. B. Bégouta i J. Kesslera: De la synthèse passive, Grenoble 1998).

15 G. Deleuze, Logika sensu, s. 166.

Sens jest zawsze efektem, wytworem, produktem czegoś innego niż on sam, że sens nie rodzi się z sensu, że jest hetero-geniczny 
Sens nie jest pierwotny, konstytutywny, lecz konstytuowany w określonych warunkach. I właśnie do tych warunków możliwości sensu stara się dotrzeć Deleuze, dokonując radykalnego przeformułowania programu filozofii transcendentalnej. Jego podstawowa zasada głosi, że „fundament nigdy nie może być podobny temu, co się na nim opiera" ${ }^{16}$. Owo podobieństwo, które ma zostać zniesione, zatarte, dotyczy samej formy Tego Samego. Z faktu, że sens już ukonstytuowany jest jednokierunkowy i daje się zidentyfikować jako ten sam w różnych wypowiedziach, nie wynika, że to, co go produkuje, również podlega zasadzie jednego słusznego kierunku i zasadzie tożsamości. A już na pewno nie wynika z niego teza o Osobie bądź Ego (czy innej postaci podmiotu transcendentalnego) jako instancji odpowiedzialnej za ową produkcję. Nawet jeśli sens jest „subiektywny", proces jego generowania nie musi odsyłać do żadnej subiektywności. Czy jednak pozbywając się tych arbitralnych wyobrażeń co do organizacji pola transcendentalnego - wynikających z bezkrytycznego ulegania nawet przez najbardziej krytycznych filozofów zdrowemu rozsądkowi i zmysłowi wspólnemu - nie wykraczamy poza ramy transcendentalizmu? Na ile można tu jeszcze mówić o „warunkach możliwości” sensu, na ile zaś jego wyłanianie się stanowi efekt złożonych, wielokierunkowych oddziaływań o charakterze empirycznym? „Stawką podwójnej walki jest tutaj zażegnanie wszelkiego dogmatycznego pomieszania wydarzeń z esencjami, ale również wszelkiego empirycznego pomieszania wydarzenia z wypadkiem"17. Stąd Deleuzjański empiryzm transcendentalny, niebędący ani klasycznym transcendentalizmem (o ile ten ostatni poszukuje właśnie esencji, względnie konstytuującego sens czystego Ja), ani prostym badaniem empirycznym (o ile to ostatnie redukuje sens do wypadkowej fizycznych stanów rzeczy). Stąd jednak także, w ramach samej logiki sensu, figura dwóch kierunków genezy.

$\mathrm{Z}$ jednej strony (albo uwzględniając jeden kierunek) trzeba powiedzieć, że niecielesny, idealny sens wydarza się jako efekt interakcji ciał, wytwór „cielesnych mieszanin”, jak powiada Deleuze, odwołując się do fizyki stoickiej (każde ciało jest tu właśnie mieszanina). Z drugiej zaś - że same ciała, na równi ze zdaniami, które - zgodnie ze swymi trzema aspektami - desygnują stany rzeczy, manifestują podmiot i znaczą relacje logicznego wynikania, okazują się wytworem albo „ucieleśnieniem” niecielesnych wydarzeń. Jak pogodzić ze sobą te dwa kierunki? Jak pomyśleć paradoks sensu będącego jednocześnie efektem, który zarysowuje się na powierzchni ciał, i tym, co - samo niewzruszone i neutralne - generuje ciała i sensowne zdania?

16 Tamże, s. 143.

17 Tamże, s. 85. 
Właśnie w tym drugim znaczeniu sens jawi się jako to, co transcendentalne, a więc niejako pierwsze, jako warunek możliwości sensu ukonstytuowanego i wyrażonego w zdaniu. Pojawia się zatem podwójna trudność - dwa przeciwne kierunki genezy, a do tego jeszcze podwójne znaczenie sensu: raz jako ukonstytuowanego, raz jako tego, co konstytutywne. Ta ostatnia dwuznaczność zdaje się przeczyć wyjściowej zasadzie hetero-geniczności (niepodobieństwa warunkowanego do jego warunku). Sens zdania okazuje się ostatecznie wytworem... sensu rozumianego jako niewzruszone (całkowicie obojętne i neutralne wobec ciał i zdań, które wytwarza) wydarzenie. Kiedy jednak przyjrzymy się sposobowi, w jaki Deleuze opisuje działanie owej niewzruszonej instancji, dostrzeżemy, że transcendentalna organizacja sensu w niczym nie przypomina żadnej znanej nam „sensownej” organizacji. Właśnie dlatego do jej opisu potrzeba nowych pojęć. Niewzruszony sens z punktu widzenia zdrowego rozsądku i zmysłu wspólnego okazuje się raczej bezsensem w postaci generujących sens, ale pozbawionych go struktur („strukturalizm wykazuje, że sens tworzy się z nonsensu i z jego ciągłego przemieszczenia, że rodzi się on dzięki odpowiednim pozycjom elementów, które same w sobie wcale nie są "znaczące«"18) lub w formie „bezosobowego i preindywidualnego pola transcendentalnego” ${ }^{19}$. Ostatecznie nie ma zresztą istotowej różnicy między tymi określeniami, jako że „struktura”, sama posiadająca właśnie charakter bezosobowy i preindywidualny, stanowi tylko jedno z imion tego, co transcendentalne, warunku wszelkiej osobowości i indywiduacji. Na podobnej zasadzie - a więc, raz jeszcze, dzięki przekroczeniu formy zdrowego rozsądku i zmysłu wspólnego - daje się ominąć także pierwszy problem. Tak jak bezosobowe struktury nie są esencjami, podobnie cielesne mieszaniny, o ile wytwarzają sens (i stają się przez to przedmiotem wyższego empiryzmu ${ }^{20}$ ), nie są po prostu ciałami (ukonstytuowanymi, wykrystalizowanymi, stabilnymi przedmiotami możliwego rozpoznania w zdaniu typu „to jest x”). „Powstawanie sensu z ciał oznacza coś całkiem szczególnego. Tym razem chodzi o ciała ujęte w ich niezróżnicowanej głębi, w ich pulsowaniu pozbawionym jakiejkolwiek miary. Głębia ta działa w bardzo oryginalny sposób: dzięki zdolności do organizowania powierzchni i do przyoblekania się w powierzchnie" 21 .

Właśnie w tym paradoksalnym miejscu, na powierzchni, czysta logika niewzruszonego sensu-struktury zbiega się ostatecznie z cielesną, a zara-

18 Tamże, s. 107.

19 Tamże, s. 148.

20 Czyli takiego, w którym sama zmysłowość „wchodzi w rozstrojoną grę”, a ,jej organy stają się metafizyczne” (G. Deleuze, Różnica i powtórzenie, s. 207).

21 G. Deleuze, Logika sensu, s. 175. 
zem sensotwórczą fizyką. Ciała wytwarzają sens tylko o tyle, o ile na pewnym poziomie swojej organizacji wymykają się naiwnemu empiryzmowi i upodabniają do hiperzłożonych struktur. Zarówno osiąganie niewzruszoności, jak i wydobywanie się na powierzchnię stanowi jednak zarazem imperatyw etyczny. Przejdźmy więc teraz do drugiej Logiki.

\section{II}

Problem moralny albo etyczny pojawia się właśnie na przecięciu płaszczyzny myślenia z życiem

$\mathrm{Na}$ samym początku serii dwudziestej ( $O$ problemie moralnym wedtug stoików) Deleuze przywołuje, za Diogenesem Laertiosem, stoickie porównanie filozofii do jaja. Logika to jego skorupka, fizyka - spoczywające w głębi żóttko, białku zaś, które mieści się między nimi, odpowiada etyka. I zaraz dodaje: „Czujemy jednak, że jest to już pewna racjonalizacja. Trzeba by dotrzeć do pierwotnego aforyzmu-anegdoty"22. Fragment ten warto zestawić z innym, w którym mowa o tym, że „nie należy zadowalać się ani biografią, ani bibliografią, należy dotrzeć do owego tajemnego punktu, w którym to samo staje się jednocześnie anegdotą z życia i aforyzmem w sferze myśli’”23. Problem moralny albo etyczny pojawia się właśnie na przecięciu płaszczyzny myślenia z życiem, tam, gdzie życie może stać się przedmiotem afirmacji ze strony myśli lub zostać przez nią zanegowane, zredukowane, umniejszone. Najwyraźniej jest to problem tyleż stoicki, co nietzscheański...

W Logice sensu synonim życia jako możliwego przedmiotu afirmacji stanowi wydarzenie. Stąd genialna w swojej prostocie Deleuzjańska formuła moralności, która „mówi nam jedynie tyle, że nie powinniśmy być niegodni tego, co nam się przydarza”24. Jeśli jednak zastanowimy się nad jej znaczeniem, szybko dojdziemy do wniosku, że prostota jest tu jedynie pozorna. Co to znaczy: być godnym tego, co nam się przydarza, być godnym wydarzenia? Kłopot z ową formulą jest podobny do tego, jaki wciąż mamy chyba z Nietzschego teorią wiecznego powrotu - nic dziwnego, że Deleuze, przybliżając jej właściwy sens, co i rusz odwołuje się właśnie do tej teorii i jej rozmaitych wykładni. Podobieństwo jest, po pierwsze, czysto formalne. Tak jak w wypadku pojęcia Nietzscheańskiego, mamy tu do czynienia z aforyzmem, który w najprostszej, najbardziej dosłownej interpretacji wydaje się zbyt banalny, by udźwignąć myślowy ciężar, jaki niesie zgodnie z deklaracją samego filozofa.

22 Tamże, s. 195.

23 Tamże, s. 179.

24 Tamże, s. 204. 
W związku z wiecznym powrotem nieraz zwracano uwagę na osobliwą dysproporcję między kardynalnym znaczeniem, jakie - w listach i rozmowach - przyznawał mu Nietzsche w ramach swej koncepcji, oryginalnością, do której rościł sobie pretensję właśnie w tym punkcie, a wtórnością owej wizji, w której to samo wiecznie powraca w nieskończonych cyklach. Czy znawca filozofii starożytnej zapomniał, że już stoicy głosili cykliczność bytu? Czyżby nie pamiętał o Heraklicie i jego teorii cyklicznego spalania się [ekpyrosis] świata ${ }^{25}$ ? Poza tym czy obraz wiecznego powracania tych samych stanów rzeczy można dziś traktować jako „poważną” propozycję ontologiczną? I czy da się ona pogodzić z Nietzscheańską filozofią stawania się, przeciwstawionego statycznemu, tautologicznemu bytowi? Tak samo jest z formułą Deleuze’a. Gdyby „bycie godnym tego, co się nam przydarza”, oznaczało jedynie przyjmowanie „z godnością” wszelkich życiowych wypadków, to Deleuze musiałby się jawić jako dość po-niewczesny epigon stoickiej etyki akceptacji koniecznego biegu rzeczy. Jednakże ani etyka amor fati, ani stoicka fizyka nie są - jak pokazuje to właśnie Logika sensu - niczym oczywistym. Tu kończy się też analogia formalna, a zaczyna dużo bardziej istotny związek na poziomie treści. Problem afirmacji wiecznego powrotu i problem afirmacji wydarzenia to z pewnego punktu widzenia ten sam problem etyczny, odsyłający jednocześnie do fizycznego zagadnienia konieczności, jakiej podlegają ciała, i do logicznego zagadnienia stawania się. W obu tych kierunkach.

Problem moralny, według stoików, brzmi: „w jaki sposób można uchwycić wydarzenie i pragnąć go, nie odsyłając zarazem do wytwarzającej go cielesnej przyczyny, a za jej pośrednictwem - do całkowitego zbioru przyczyn, czyli do physis?”26. Albo, inaczej: jak afirmować wydarzenie, nie popadając w bierny fatalizm, akceptację konieczności? Nietzsche również mierzył się z tą trudnością w Zaratustrze: „Wszystko [...] żuć i przetrawiać - to jest natura świń! Ciągle mówić potakujące »a-ha» - tego nauczył się nawet osioł i każdy, kto jest z jego ducha" ${ }^{27}$. Słowa te nieprzypadkowo padają w rozdziale $O$ duchu ciężkości. Rzecz w tym, że nauka o wiecznym powrocie sama sprawia wrażenie tak ciężkiej i obciążającej, że trudno ją zrazu odróżnić od bezmyślnego, oślego „a-ha”. Niebezpieczeństwo owej ciężkiej wykładni nigdy nie zostaje do końca zaże-

25 F. Nietzsche, Filozofia w tragicznej epoce Greków, [w:] tegoż, Pisma pozostate 1862-1875, tłum. B. Baran, Kraków 1993, s. 133.

26 Tamże, s. 196.

27 F. Nietzsche, To rzekt Zaratustra: książka dla wszystkich i dla nikogo, tłum. S. Lisiecka, Z. Jaskuła, Warszawa 1999, s. 250. 
Bycie godnym tego, co się nam przydarza, nie oznacza akceptacji konieczności, że potrzeba tu czegoś wręcz przeciwnego gnane, stale zagraża Zaratustrze, czasem pojawiając się z najmniej oczekiwanej strony, jak wtedy, gdy jego zwierzęta intonują: „Wszystko odchodzi, wszystko powraca; wiecznie toczy się koło bytu"28. Nauczyciel wiecznego powrotu wie, że jego pieśń nazbyt łatwo może przerodzić się $\mathrm{w}$ „katarynkową śpiewkę liryczną ${ }^{29}$. Wieczne To Samo - to myśl najcięższa, a zarazem niebezpiecznie podobna do jego własnej myśli. Wypowiada ją również obmierzły „pół karzeł, pół kret, bezwładny, obezwładniający”, który siedzi na ramionach Zaratustry: „Wszelka prawda jest pokrętna, sam czas jest kołem" ${ }^{30}$. Czy myśl ta nie przypomina jednak także stoickiej teorii przeznaczenia, które niepodzielnie rządzi biegiem rzeczy i przed którym należy się ugiąćc? Otóż Deleuze przekonuje, że stoikom udaje się wydostać z pułapki fatalizmu za pomocą pewnego wynalazku natury pojęciowej. Wprowadzają oni mianowicie

nowy podział w ramach relacji przyczynowej. [...] Odsyłają przyczyny do przyczyn, potwierdzając łączący je związek przyczynowy (przeznaczenie), skutki zaś odsyłają do skutków, również między nimi ustalając pewne związki. Te ostatnie mają jednak zupełnie inny charakter: bezcielesne skutki nie są nigdy jedne dla drugich przyczynami, lecz wyłącznie „pseudoprzyczynami”"

W ten sposób stoicyzm może - właśnie na poziomie wolnych skutków-wydarzeń, których wytwarzanie jest racją istnienia przyczyn jako takich - przeciwstawiać przeznaczenie konieczności, inaczej niż epikureizm, który - za sprawą pojęcia clinamen, odchylenia ruchu atomów - próbuje myśleć przyczynowość bez przeznaczenia. Wszystko to jest Deleuze'owi potrzebne do tego, by pokazać, że bycie godnym tego, co się nam przydarza, nie oznacza akceptacji konieczności, że potrzeba tu czegoś wręcz przeciwnego.

„Kolistość” czasu oznacza przede wszystkim brak początku i końca, bezmierność samego stawania się. Dlatego właściwy sens wiecznego powrotu, zatarty w dosłownej, banalnej wykładni, „polega na tym, że w żadnej mierze nie wyraża on porządku, który przeciwstawiałby się chaosowi lub go opanowywat. Wprost przeciwnie - nie jest on niczym innym jak chaosem, mocą afirmacji chaosu"32. I na tym, zdaje się, polega też problem moralny neostoika Deleuze’a - jak afirmować chaos albo stawanie się? Jak afirmować czyste wydarzenie jako „pseudoprzyczynę”?

28 Tamże, s. 278.

29 Tamże, s. 279.

30 Tamże, s. 204-205.

31 G. Deleuze, Logika sensu, s. 21-22.

32 Tamże, s. 347-348. 
Pierwsza odpowiedź, jakiej udziela na to pytanie już w serii dziesiątej a więc na dobrą sprawę jeszcze przed jego zadaniem - wydaje się całkiem naturalna i zgodna z naszą wyjściową intuicją: „afirmować cały przypadek, czynić przypadek przedmiotem afirmacji - do tego zdolna jest wyłącznie myśl”33. Tylko czysta myśl jest w stanie dotrzeć do tego, co bezcielesne, do sensu jako niewzruszonego, neutralnego wydarzenia, oparu unoszącego się nad cielesnymi mieszaninami. Deleuze z całą pewnością należał do tych - być może coraz mniej licznych - filozofów, którzy w dwudziestym wieku zachowali niezachwianą wiarę w moc myślenia. Jedną z najbardziej dobitnych manifestacji tej wiary jest właśnie Logika sensu, z jej teorią „płaszczyzny metafizycznej” i przejścia „od ust do mózgu”, umożliwiającego narodziny sensownej mowy. Znajduje ona jednak wyraz także i później, aż do ostatniej, napisanej wraz z Félixem Guattarim książki poświęconej filozofii jako formie myśli. Są rzeczy, o których da się tylko myśleć, właściwe „rzeczy myślenia”, które potrafi ono sproblematyzować dzięki swej nieskończonej prędkości. A ściślej rzecz biorąc - jest to właśnie cząstka chaosu tkwiąca w każdej rzeczy. Tylko myśl, w szczególności myśl filozoficzna, trwa przy tym, co chaotyczne, nie szukając schronienia w doksie ${ }^{34}$. Dodatkowo wątek ten daje się łatwo uzgodnić ze stoicyzmem Deleuze'a - czyż stoicy nie twierdzili, że prawdziwą wolność człowiek osiąga jedynie w sferze myśli albo przedstawień, tylko te bowiem, w odróżnieniu od fizycznych stanów rzeczy, pozostają pod jego kontrolą? Musimy być jednak czujni. Lektura Deleuze’a jak mało co sprawia wszak, że rozstajemy się z obiegowymi wykładniami problemów i „naturalnymi” odpowiedziami na rozmaite pytania.

Gdy mowa o bezcielesnych wydarzeniach, nieprzypadkowo powracają zawsze podobne przykłady. Joë Bousquet mówiący: „moja rana istniała już przede mną, urodziłem się po to, by ją urzeczywistnić"35. Konsul z powieści Lowry'ego w stanie permanentnego delirium zmierzający ku ostatecznej katastrofie. Bohaterowie Fitzgeralda, którzy „nie próbowali dokonać niczego nadzwyczajnego, co byłoby ponad ich siły, a przecież budzą się niczym po bitwie, która ich przerosła, załamani na ciele, z nadwyrężonymi mięśniami, obumarli na duchu" ${ }^{36}$. Wszędzie pojawia się owo załamanie, pęknięcie - to właśnie ono „nie jest ani

33 Tamże, s. 94.

34 Zob. G. Deleuze, F. Guattari, Co to jest filozofia?, tłum. P. Pieniążek, Gdańsk 2000, s. 229-230.

35 G. Delezue, Logika sensu, s. 203.

36 Tamże, s. 210. 
wewnętrzne, ani zewnętrzne” ${ }^{37}$, lecz „na granicy, pozazmysłowe, bezcielesne, idealne”. „Wszelkie życie jest, rzecz jasna, procesem rozpadu. [...] Całe dzieło Fitzgeralda - powiada Deleuze - sprowadza się do swoistego rozwinięcia tej frazy, zwłaszcza owego »rzecz jasna «" ${ }^{38}$. I wreszcie sama śmierć, splendor śmierci „bezcielesnej, bezokolicznikowej, bezosobowej” ${ }^{39}$, niewzruszoność owego umiera-się, które egzorcyzmował Heidegger i które tryumfalnie powraca w dziele Maurice’a Blanchota. „Czy są to tylko przykłady? A może każde wydarzenie ma w sobie coś z [...] bitwy czy skaleczenia - sięga tym głębiej, że dzieje się na powierzchni, jest tym bardziej bezcielesne, że przebiega wzdłuż ciał?” ${ }^{40}$. Zgodnie z podwójnym kierunkiem genezy bezcielesny sens stanowi jednocześnie powierzchniowy efekt oddziaływań między ciałami oraz to, co się w nich ucieleśnia - tak czy inaczej, ciała nie da się wymazać. Bycie godnym wydarzenia musi zatem wiązać się zarówno ze zdolnością jego afirmacji przez myśl, jak i z jego doświadczeniem na wtasnej skórze, to zaś oznacza zawsze ranę, i to ranę śmiertelną. Jak pogodzić ze sobą, tym razem w wymiarze etycznym, dwa kierunki, afirmację stawania się przez czystą myśl i urzeczywistnienie wydarzenia we własnym ciele?

Tak jak etyka mieści się między logiczną skorupką a głębią fizycznego żółtka, i tak jak wydarzenie jest jednocześnie bezcielesnym i czymś, co stanowi powierzchniowy efekt mieszania się ciał, a także (zgodnie z drugim kierunkiem genezy) samo się w nich ucieleśnia, tak afirmacja wydarzenia ma nieodmiennie dwa uzupełniające się aspekty albo dwa oblicza. Najwyższej mocy pojęcia towarzyszy tu swoisty atletyzm ${ }^{41}$. „Nie wiemy, do czego zdolne jest ciało”, powiada Deleuze za Spinozą. Wydarzenie jest tym, co poddaje ciało próbie, testuje granice jego możliwości, jest właściwym życiem ciała, co oznacza jednak także, „rzecz jasna”, proces rozpadu. Należy tu jednak zastrzec, że - podobnie jak cielesne mieszaniny odpowiedzialne za dynamiczną genezę sensu - owo żyjące i rozpadające się ciało nie jest po prostu organizmem czy konstelacją stanów rzeczy. Wciąż obowiązuje zasada wyższego empiryzmu, każąca ujmować same ciała „w ich pulsowaniu pozbawionym jakiejkolwiek miary”. Nie chodzi więc o prostą degrengoladę czy dysfunkcjonalność

37 Tamże, s. 211.

38 Tamże, s. 210.

39 Tamże, s. 207.

40 Tamże, s. 27.

41 Zob. G. Deleuze, Francis Bacon: logique de la sensation, Paris 2002 (wyd. 1 1981), s. 21-26. „Atletyzm” oznacza tu szczególny, nadludzki wysiłek figur Bacona, wysiłek ciała próbującego w spazmie, krzyku i najwyższym napięciu „wymknąć się samemu sobie”; poszukującego swej „linii ujścia”. 
ciała, lecz o jego eksperymentalną deregulację, pozwalającą czasem odkryć albo raczej wytworzyć funkcje całkowicie nowe, nieznane. To właśnie nazywa Deleuze cielesnym „przeciwurzeczywistnieniem” wydarzenia. „Wiecznej prawdy” tego ostatniego „nie da się uchwycić, jeśli wydarzenie nie wpisze się również w ciało; za każdym razem wszelako trzeba podwajać to bolesne urzeczywistnienie ograniczającym je, odgrywającym i przeistaczającym przeciwurzeczywistnieniem"42. Wówczas nawet choroba może stać się wydarzeniem, którego trzeba okazać się godnym, tak jak w wypadku Nietzschego:

trajektoria owego wydarzenia, które stanowiło inspirację dla całego dzieła, a częściowo także dla życia, nie ma przecież nic wspólnego z ogólnym paraliżem, z migrenami ocznymi czy z wymiotami, na które cierpiał Nietzsche, chyba że w sensie nadania temu wszystkiemu zupełnie nowej przyczynowości, to znaczy: wiecznej prawdy, niezależnej od cielesnego urzeczywistnienia, w sensie stylu dzieła wkraczającego na miejsce mieszanin ciała ${ }^{43}$.

Tak oto ponownie docieramy jednak do konieczności myślenia. W końcówce serii dwudziestej drugiej (Porcelana i wulkan) Deleuze przywołuje słowa Burroughsa: „wszystko, co da się osiągnąć za pomocą środków chemicznych, można też osiągnąć inaczej" ${ }^{44}$. Jak? Łącząc eksperymentalny atletyzm ciała $\mathrm{z}$ atletyzmem myśli...

Właściwym problemem moralnym, według Logiki sensu, jest problem „innego zdrowia”, będącego „niczym ciało zdolne przetrwać własną ranę”45. I w pewien sposób pozostaje nim także później, gdy - w Anty-Edypie ciało-maszyna podłączy się do innych maszyn. W międzyczasie dokonuje się jednak wyraźna zmiana tonu. Śmierć, rana i choroba schodzą na dalszy plan, ustępując miejsca innym katalizatorom stawania się. Nawet sama schizofrenia jest tu nie tyle chorobą, ile czystą mocą rojenia [délire] i odjazdu [dérive]. Niewzruszoność i wieczna prawda sensu wydarzenia zostają zastąpione przez pragnienie. Zmianę tę zapowiadają już zresztą niektóre fragmenty Logiki, zwłaszcza te poświęcone Tournierowskiemu Robinsonowi, „który staje się bytem elementarnym na swojej wyspie, bez reszty oddającej się we władanie żywiołów: słoneczny Robinson na

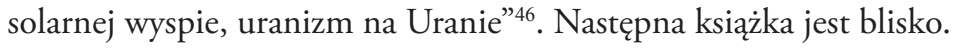

42 G. Deleuze, Logika sensu, s. 219.

43 Tamże, s. 156.

44 Tamże, s. 220.

45 Tamże, s. 219.

46 Tamże, s. 398. 
Michał Herer - ur. 1977, od 2004 roku wykłada w Instytucie Filozofii UW. Zajmuje się problematyką współczesnej myśli krytycznej. Autor monografii Gilles Deleuze: Struktury - Maszyny - Kreacje (Kraków 2006) oraz esejów na temat filozofii nowożytnej i współczesnej, poświęconych między innymi Spinozie, Heglowi, Kierkegaardowi, Bataille'owi i Adornowi. Tłumacz Foucaulta, Deleuze’a i Althussera.

Dane adresowe autora:

Instytut Filozofii UW

Krakowskie Przedmieście 3

00-927 Warszawa

e-mail: michal.herer@gmail.com

Cytowanie:

M. Herer, Od ontologii do etyki wydarzenia, „Praktyka Teoretyczna” nr 5/2012, http://www.praktykateoretyczna.pl/PT_nr5_2012_Logika_ sensu/06.Herer.pdf (dostęp dzień miesiąc rok)

Author: Michał Herer

Title: From Ontology To the Ethics of the Event

Summary: The text is an attempt of a double reading of Gilles Deleuze's Logic of Sense as an otology of incorporeal events as well as an ethics calling for "being worthy of what happens to us". The first aspect refers to the necessity of overcoming phenomenology and revisiting the foundations of transcendentalism, while in his ethics of the event Deleuze draws inspiration from stoics and Nietzsche, as well as writers like Bousquet, Lowry and Fitzgerald. It is an ethics based on the imperative of affirmation of the world as becoming - an affirmation both on the level or surface of the pure thought and in one's own body, for which such an act means always a kind of wound or the threat of breakdown.

Key words: the incorporeal, event, sense, paradox, ethics, eternal return, stoics, affirmation, athleticism. 